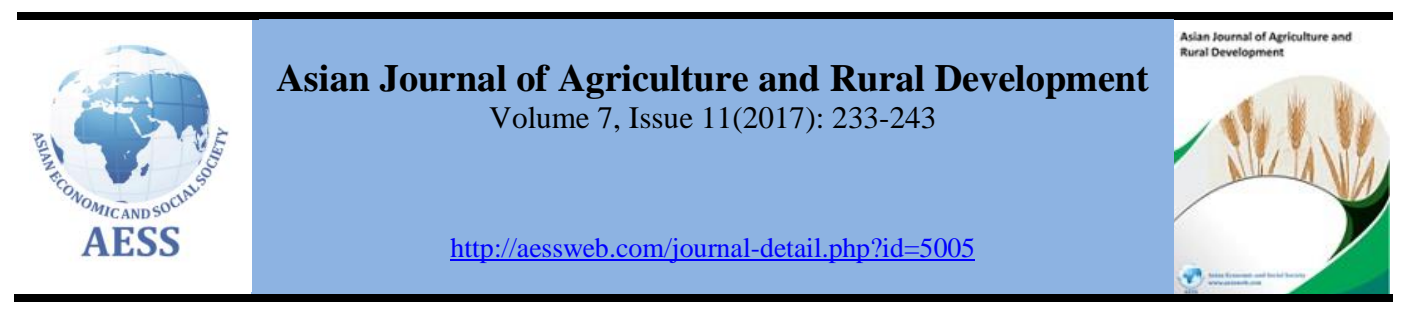

\title{
Morpho-physiology, yield and quality assessment on five local landrace Chilli Germplasms
}
Md. Shah Newaz Chowdhury ${ }^{a}$, Shahnaz Sarkara, AFM Jamal Uddin $^{\text {b }}$, Tania Sultana ${ }^{c^{*}}$, MZK Roni $^{\mathrm{d}}$, Rabiul Islam ${ }^{\mathrm{e}}$
a Department of Agricultural Botany, Sher-e-Bangla Agricultural University, Dhaka-1207, Bangladesh
b Professor, Department of Horticulture, Sher-e-Bangla Agricultural University, Dhaka-1207, Bangladesh
$\mathrm{c}^{*}$ Assistant Professor, Department of Agroforestry and Environmental Science, Sher-e-Bangla Agricultural University, Dhaka-1207, Bangladesh
d The United Graduate School of Agricultural Sciences, Ehime University, 2 3-5-7 Tarami, Matsumaya, Ehime 790-8556, Japan
${ }^{\mathrm{e}}$ Department of Agricultural Chemistry, Sher-e-Bangla Agricultural University, Dhaka-1207, Bangladesh
*Email address: kbdtania06@yahoo.com (Corresponding Author)

\section{ARTICLE HISTORY:}

Received: 03-May-2018 Accepted: 04-Jun-2018 Online available: 20 -Jun2018

\section{Keywords:}

Capsicum frutescens, Fresh fruit plant ${ }^{-1}$, Vitamin-C, Yield

\begin{abstract}
An experiment was arranged to evaluate the morpho-physiological characters, yield and quality of local landrace chilli germplasms, Sher-e-Bangla Agricultural University, Dhaka, from October 2013 to July 2014. The experiment was laid out in Randomized Complete Block Design with four replications. Among germplasms, maximum plant height $(59.5 \mathrm{~cm})$ and leaves (84.1) from 'Kajoli'. Number of branches (33.1) was from 'Akashi' minimum (18.6) from 'Dongfou', chlorophyll content (56.9\%) was obtained from 'Kajoli', whereas minimum (48.9\%) was obtained from 'Dongfou'. Leaf area highest $\left(125.8 \mathrm{~cm}^{2}\right)$ from 'Dongfou', whereas lowest $\left(62.38 \mathrm{~cm}^{2}\right)$ from 'Deshi kacha Morich'; was recorded as at 85 DAT. Highest flowers plant ${ }^{-1}$ (68.7), number of fruits plant ${ }^{-1}$ (268.3) were found in 'Kajoli', whilst lowest (24.6) and (61.42) were for 'Dongfou'. Maximum vitamin-C was found in green and dry chilli fruits $(76.44 \mathrm{mg} / 100 \mathrm{~g}$ and $42.55 \mathrm{mg} / 100 \mathrm{~g})$, of the germplasm 'Akashi' and minimum vitamin-C was recorded in green and dry fruits from 'Deshi kacha morich'. The germplasm 'Akashi' gave the highest fresh fruits yield $\left(18.1 \mathrm{t} \mathrm{ha}^{-1}\right)$, followed by Deshi kacha morich $\left(16.9 \mathrm{t} \mathrm{ha}^{-1}\right)$ and Bogra morich produced the lowest fresh yield $\left(13.3 \mathrm{t} \mathrm{ha}^{-1}\right)$. In view of overall performances, So, Akashi with was best for higher fruit, yield and quality chilli production.
\end{abstract}

Contribution/ Originality

In this paper, authors analyzed the the morpho-physiological characters, yield and quality of local landrace chilli germplasms and found interesting results.

DOI: 10.18488/journal.1005/2017.7.11/1005.11.233.243

ISSN (P): 2304-1455/ISSN (E):2224-4433

Citation: Md. Shah Newaz Chowdhury, Shahnaz Sarkar, AFM Jamal Uddin, Tania Sultana, MZK Roni and Rabiul Islam (2017). Morpho-physiology, yield and quality assessment on five local landrace Chilli Germplasms. Asian Journal of Agriculture and Rural Development, 7(11), 233-243.

(C) 2017 Asian Economic and Social Society. All rights reserved. 


\section{INTRODUCTION}

Chilli (Capsicum frutescens) belongs to the Solanaceae family, a year round crop used in variety of ways (Erinle, 1989; Akinyosoye, 1977). It is an unavoidable spice, which is liked for its pungency, spicy taste and its appealing color adds to the curry. Refers to fruit which is usually cone-shaped, smaller and the pungency may be very mild to intensely hot. Among these peepers $C$. frutescens are hot and C. annum are sweet. Hot peppers (chillies) pericarp have high content of crystalline colorless pungent substance known as alkaloid capsaicin $\left(\mathrm{C}_{18} \mathrm{H}_{27} \mathrm{NO}_{3}\right)$ (Udoh et al., 2005). It is quite rich in nutritive values and supposed to contain certain medicinal properties (Chowdhury, 1976). In fact, they are an excellent source of various antioxidant compounds like flavonoids, Shercarotenoids and Vitamin-C (Chuah et al., 2008).Green chillies are rich in vitamin $A$ and $C$ and the seed contain traces of starch (Sayed and Bagavandas, 1980). In addition, peppers are a good source of vitamin-B and vitamin $\mathrm{B}_{6}$, carbohydrate, carotene, thiamine, riboflavin and niacin. In Bangladesh, chillies are grown in all the districts but plenty of chillies are produced in district of Bogra, Rangpur, Kurigram, Jamalpur, Natore and Jessore (BBS, 2014). 16141.73 hectares of land is under chilli cultivation in Bangladesh where 21,000 metric tons of chilli produced per annum in kharif season.105,000 tons of chilli was produced from 78346.45 hectares of land in rabi season. A numbers of cultivars are grown in Bangladesh differing in habit and yield but green chilli production was only $16.9 \mathrm{t} \mathrm{ha}^{-1}$ during 2010-2011 (BBS, 2011). This yield is very low compared to that of other chilli growing countries of the world. For the low yield of the crop, its annual production cannot meet up the total requirement and as such large quantity is to be imported every year. The low yield of chilli in Bangladesh may be attributed to a number of reasons such as unavailability of quality seeds of high yielding germplasm, lack of screening of local germplasm, lack of disease and insect of the available cultivars. Low yield in Bangladesh could be attributed to lack of suitable cultivars. In our country there are a few research works conducted for focusing on the germplasm screening of chilli and their growth, yield and quality. Considering the above point in view the study was undertaken to evaluate morph physiological characters, yield and quality of local chilli germplasm.

\section{MATERIALS AND METHODS}

The experiment was arranged at Horticulture Farm, Sher-e-Bangla Agricultural University, Dhaka, during October 2013 to July 2014, to study the performance of growth and yield of five local landrace chilli germplasms. The experiment was designed in randomized block design (RBD), with four replications. The five different local chilli germplasms were subjected to consist the experiment, i.e. $\mathrm{V}_{1}$, Akashi; $\mathrm{V}_{2}$, Kajoli; $\mathrm{V}_{3}$, Deshi kacha morich; $\mathrm{V}_{4}$, Bogra morich and $\mathrm{V}_{5}$, Dongfou. Moderately low temperature and plenty of sunshine prevail during Rabi season, which is suitable for chilli cultivation in Bangladesh. The soil was sandy loam in texture with $\mathrm{pH}$ 5.45.6. The recommended dose of NPK fertilizer was applied as followed by BARI 2011. The seed of chilli were collected from the local market in northern and southern part of Bangladesh and seeds

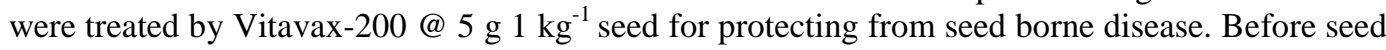
germination, the seedbed was prepared for raising seedlings and the size of the seedbed was $4 \mathrm{~m} \times$ $2 \mathrm{~m}$. Seeds were sown at a depth of $2 \mathrm{~cm}$ and covered with a fine layer of soil followed by light watering by water can. Afterwards, the unit plot size was $1.5 \mathrm{~m} \mathrm{x} 1 \mathrm{~m}$ and row to row distance were maintained as $40 \mathrm{~cm}$ for seedling growth and development in each case and applied $10 \mathrm{tha}^{-1}$ well decomposed cow dung in the main plot before seedling transplanting. Thirty days-old healthy seedlings were transplanted at the spacing of $40 \mathrm{~cm} \times 40 \mathrm{~cm}$ in the experimental plots. Thus the 16 plants were accommodated in each unit plot. Planting was done in the afternoon. Intercultural activities and watering was done, if it was necessary. During mature green chilli turned yellow, it was harvested at weekly intervals. Harvesting was started at 65 days after transplanting (DAT) and continued till 175 DAT. Data randomly selected on different parameter, for example, plant height $(\mathrm{cm})$, branches plant ${ }^{-1}$, leaf plant $^{-1}$, days to flower bud initiation after transplanting, flowers plant ${ }^{-1}$ (counting up to 60 days after first flowering), fruits plant ${ }^{-1}$, single fruit fresh weight (g), fruit 
diameter $(\mathrm{mm})$, fruit length $(\mathrm{mm}), 1000$ seed weight $(\mathrm{g})$, vitamin-C content in green chilli fruits (mg per $100 \mathrm{~g}$ fruit), vitamin-C content in dry chilli fruits ( $\mathrm{mg}$ per $100 \mathrm{~g}$ fruit), protein contain in chilli fruits (\% per $100 \mathrm{~g}$ fruit), yield plant ${ }^{-1}(\mathrm{~g})$ and fresh fruit yield $\left(\mathrm{t} \mathrm{ha}^{-1}\right)$. Growth parameters, viz., Plant height $(\mathrm{cm})$, number of branch Plant ${ }^{-1}$, number of leaf plant $^{-1}$, were recorded at 45 to 85 DAT at 10 days interval. Mature leaf from middle portion of the plant (above $20 \mathrm{~cm}$ from ground level) was used for leaf area by destructing method using CL-202 Leaf Area Meter (USA). Leaf chlorophyll content was measured by using chlorophyll meter SPAD-502. Fruit length and diameter were measured using Digital Caliper-515 (DC-515) in millimetre (mm). Fresh weight and dry weight of 50-fruits were measured by Electric Precision Balance in gram (g). Fifty randomly selected fresh fruits from each treatment were weighed and dry in room temperature. Then fifty dry fruits were weighed. 2, 6 - dichlorophenol indophenols (visual titration method) determined vitamin C content of green and dry fruits of chilli as described by Plummer (1971). Micro Kjeldahl method was determined protein content of five local chilli germplasms. To find out the significance of the experimental results data in respect of growth and yield components were statistically analyzed. All the treatments mean were calculated and for each of the characters the analysis of variance was performed by $\mathrm{F}$ test. The difference among the treatment means was evaluated by Least Significant Difference (LSD) test (Gomez and Gomez, 1984) at $5 \%$ level of probability.

\section{RESULTS AND DISSCUTION}

The experiment was observed to evaluate among the five chilli germplasms that was differentiated in terms of morphological characters, yield and quality. The performance of the five local chilli germplams is shown in Table 1.

\section{Table 1: Morphological variations in five chilli germplasm}

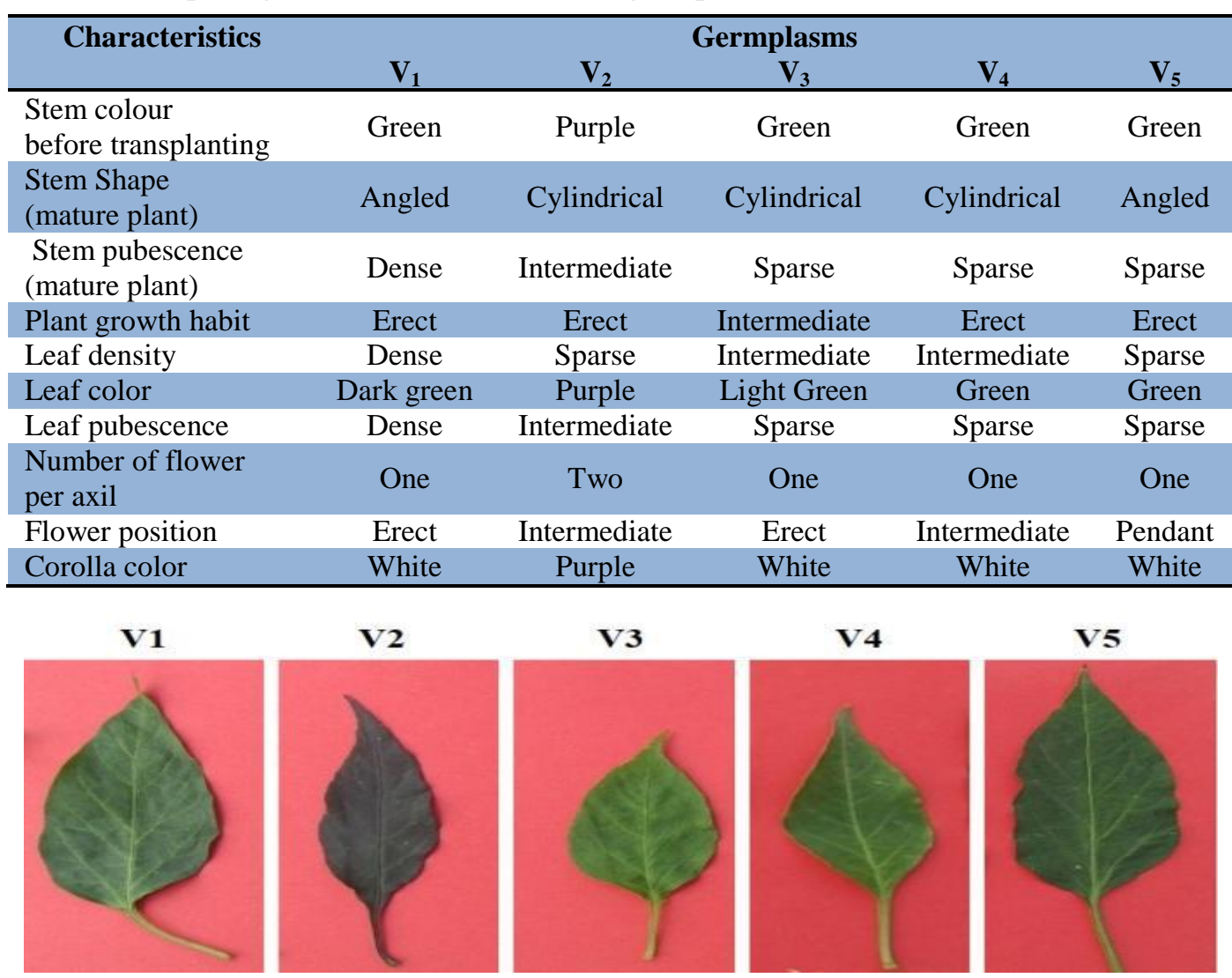

Figure 1: Mature leaf variation of five local chilli germplasm 


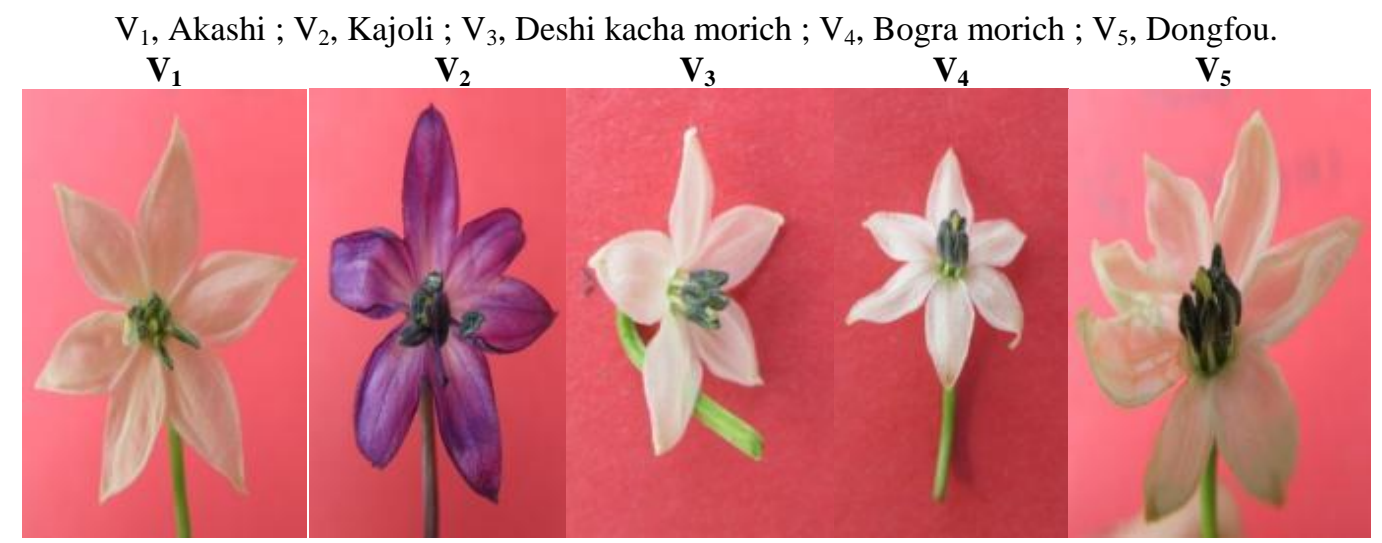

Figure 2: Flower petal and color are differentiation of chilli germplasm

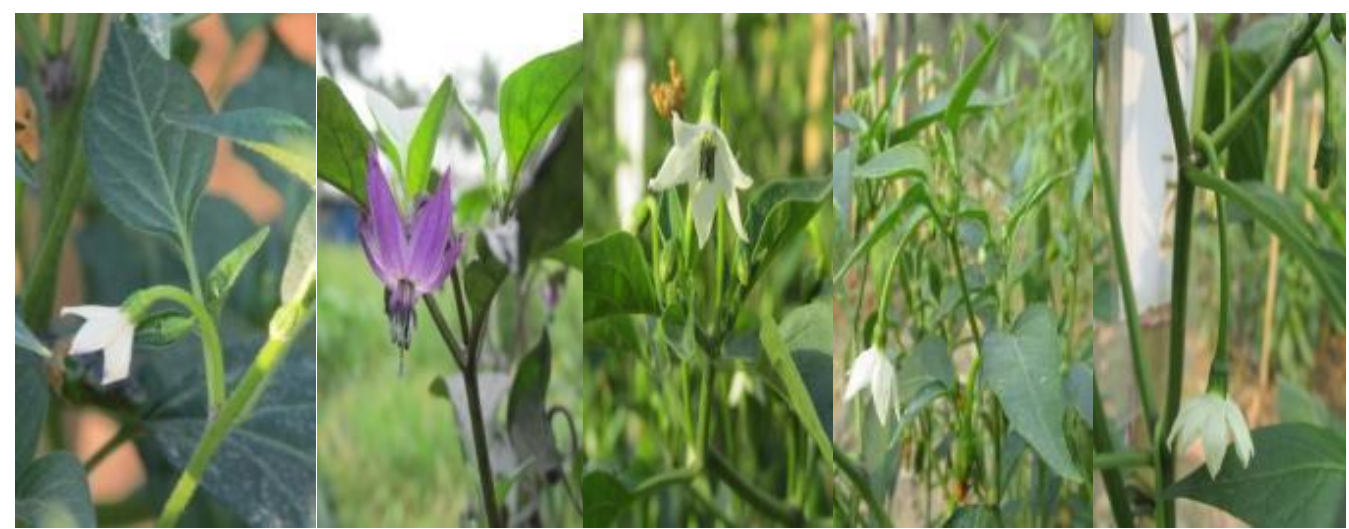

Figure 3: Variation in flower position of local chilli germplasm

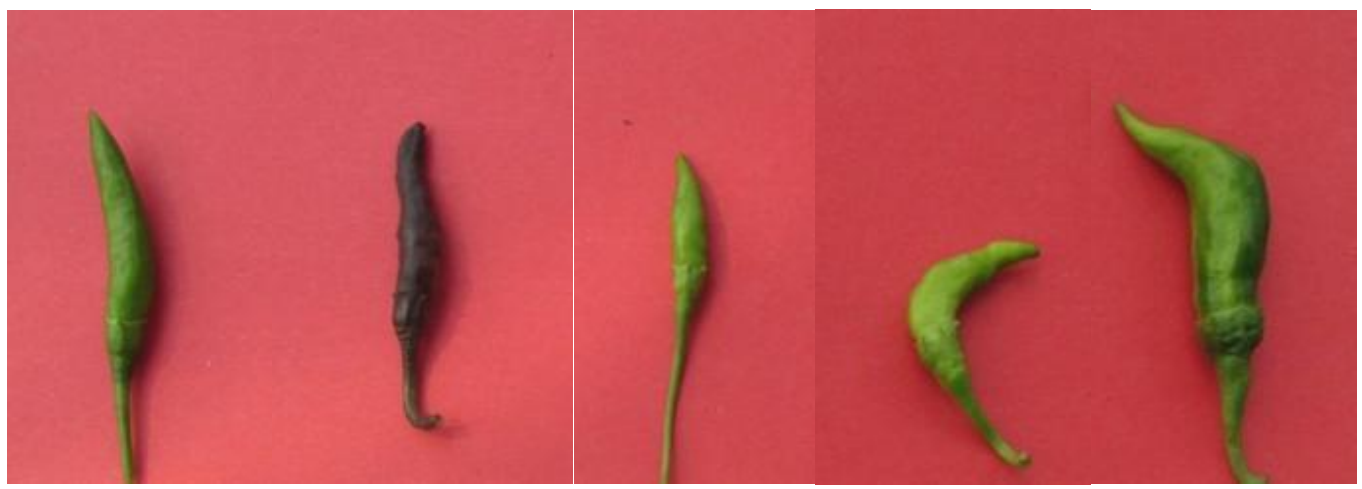

Figure 4: Variation in fruit length, shape (immature) of chilli germplasm

$\mathrm{V}_{1}$, Akashi ; $\mathrm{V}_{2}$, Kajoli ; $\mathrm{V}_{3}$, Deshi kacha morich ; $\mathrm{V}_{4}$, Bogra morich ; $\mathrm{V}_{5}$, Dongfou. 


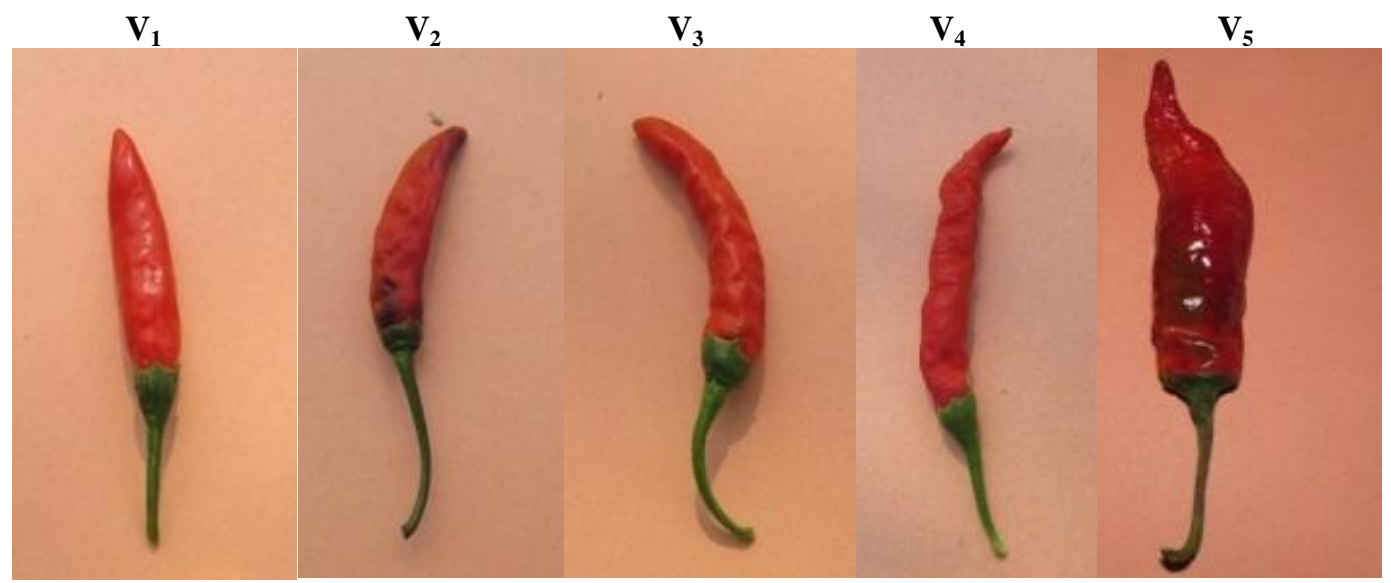

Figure 5: Fruit colour, fruit surface and length inequality of chilli germplasm

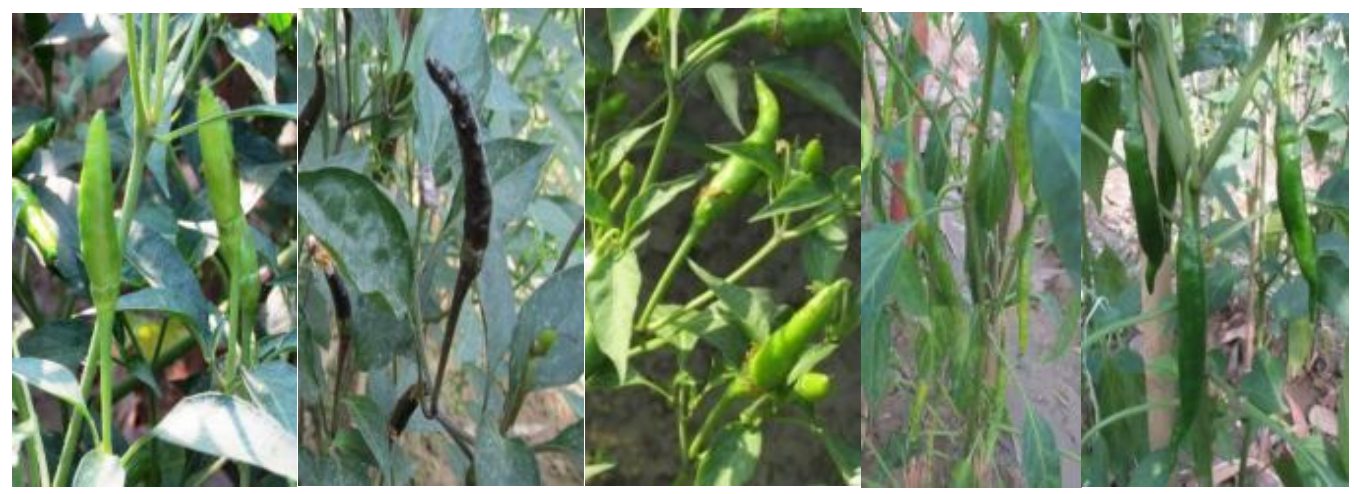

Figure 6: Variation in fruits position of chilli germplasm

$\mathrm{V}_{1}$, Akashi; $\mathrm{V}_{2}$, Kajoli ; $\mathrm{V}_{3}$, Deshi kacha morich ; $\mathrm{V}_{4}$, Bogra morich ; $\mathrm{V}_{5}$, Dongfou.

\section{Plant height}

Significant variation in plant height was observed with different chilli germplasms viz. $\left(\mathrm{V}_{1}\right.$, Akashi; $\mathrm{V}_{2}$, Kajoli; $\mathrm{V}_{3}$, Deshi kacha morich; $\mathrm{V}_{4}$, Bogra morich; $\mathrm{V}_{5}$, Dongfou) at 45, 55, 65, 75 and 85 DAT. Maximum plant height was scored from $\mathrm{V}_{2}(59.5 \mathrm{~cm})$. Minimum from $\mathrm{V}_{4}(50.7 \mathrm{~cm})$ at 85 DAT (Figure 7a) i.e., Kajoli produced maximum plant height. An increased plant height may increase the branches and leaves number of plant. There was a lot of variation in height of Capsicum plants obtained by Hosmani (1982). High phenotypic co-efficient of variation (PCV) and genotypic co-efficient of variation (GCV) were found for plant height obtained by Mini and Khader (2004); Sreelathakumary and Rajamony (2004); Ukkund et al. (2007) and Singh et al. (2009).

\section{Branches plant ${ }^{-1}$}

Significant variation was found on number of branches among the different germplasms of chilli at 45, 55, 65, 75 and 85 DAT. Maximum number of branches (33.1) was obtained from Akashi $\left(\mathrm{V}_{1}\right)$ that ware statistically similar with $\mathrm{V}_{2}$ and $\mathrm{V}_{3}$. Minimum (18.6) was observed from Dongfou $\left(\mathrm{V}_{5}\right)$ at 85 DAT (Figure 7b). Smitha and Basavaraja (2006) observed significant differences among the germplasm with respect to both quantitative and qualitative characters. Similar result was reported by Ukkund et al. (2007). 


\section{Leaf plant ${ }^{-1}$}

Leaf number of chilli germplasms did not differ significantly between $\mathrm{V}_{1}$ and $\mathrm{V}_{2}$. But statistically significant among $\mathrm{V}_{3}, \mathrm{~V}_{4}$ and $\mathrm{V}_{5}$ germplasms at 45, 55, 65, 75 and 85 DAT. Maximum number of leaves was recorded from $V_{2}(84.1)$ that are statistically similar with $V_{1}$ and $V_{2}$. Minimum from $V_{5}$ (40.4) at 85 DAT (Figure 7c).
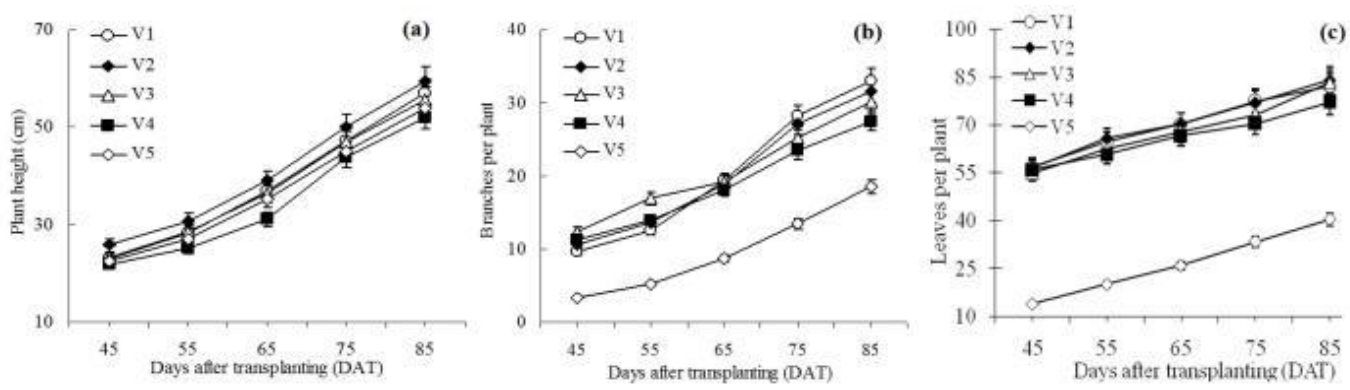

Figure 7: Performance of chilli germplasm on plant height $(\mathrm{cm})$, branches plant ${ }^{-1}$ and leaves $^{-1}$ plant $^{-1}$ of at DAT. ( $V_{1}$, Akashi ; $V_{2}$, Kajoli; $V_{3}$, Deshi kacha morich; $V_{4}$, Bogra morich; $V_{5}$, Dongfou)

\section{Chlorophyll content (SPAD values) at mature stage}

Significant variation was found on chlorophyll content (SPAD values) with different chilli germplasms at mature stage. Maximum chlorophyll content $(56.9 \%)$ was obtained from $\mathrm{V}_{2}$ (Kajoli), whereas minimum (48.9\%) was obtained from $\mathrm{V}_{5}$ (Dongfou) at 85 days after transplanting (Table 2). Chlorophyll content ranged from 60.9 to 52.8 studied among four chilli cultivars obtained by Chowdhury et al. (2015).

\section{Leaf area $\left(\mathrm{cm}^{2}\right)$}

Significant variation was observed among different chilli germplasm performance in terms of leaf area at $85 \mathrm{DAT}$. Leaf area of local chilli germplasm exposed statistically dissimilarity between $\mathrm{V}_{3}$ and $\mathrm{V}_{5}$ germplasms, whereas statistically equality found in $\mathrm{V}_{1}, \mathrm{~V}_{2}, \mathrm{~V}_{4}$ germplasms at 85 DAT. Dongfou, $\left(\mathrm{V}_{5}\right)\left(125.8 \mathrm{~cm}^{2}\right)$ was accorded top most result in term of leaf area where as $\mathrm{V}_{3}$ (Deshi Kacha Morich; $62.38 \mathrm{~cm}^{2}$ ) was recorded as inferior at 85 DAT (Table 2). According to Edwards and Ludwing (1975) unit leaf area is a valid basis for assessing the effects of short term fluctuations in environmental variables on photosynthesis.

\section{Days to first flower bud initiation after transplanting}

Significant variation in respect of days (from days after transplanting of chilli seedlings) taken for flower bud appearance (visual observation) was received among the germplasms. Longest period was required for flower bud initiation in $\mathrm{V}_{5}$ (61.1 days) whereas shortest period from $\mathrm{V}_{4}(39.1$ days) (Table 2). This result showed that $V_{4}$ was early flower bud initiating germplasm whereas $V_{5}$ was late one. Days to flower bud initiation and flowering are a basis for measuring the early or late cultivars. Days required to flowering in chilli crop mainly depend on the variety stated by Hosmani (1982), Veerapa (1980) and Ukkund et al. (2007).

\section{Flowers plant ${ }^{-1}$ (Counting up to 60 days after first flowering)}

Number of flowers per plant was significantly varied with local chilli germplasms. Number of flowers was found highest in germplasm $\mathrm{V}_{2}\left(81.00\right.$ plant $\left.^{-1}\right)$ whereas lowest in germplasm $\mathrm{V}_{5}(24.6$ plant $^{-1}$ ) (Table 2). In case of number of flowers Chilli cultivar was significantly different from one cultivar to another (Chowdhury et al., 2015; Veerapa, 1980; Hosmani, 1982) and Ruby King took 
43 days for flowering, the sweet pepper variety flowered at 27 days after transplanting (Veerapa, 1980).

\section{Weight of 50 Fresh and dry fruits}

Significant variation was found on fresh and dry weight of fifty fruits with different germplasms of chilli viz. $\mathrm{V}_{1}$ (Akashi), $\mathrm{V}_{2}$ (Kajoli), $\mathrm{V}_{3}$ (Deshi kacha morich), $\mathrm{V}_{4}$ (Bogra morich), $\mathrm{V}_{5}$ (Dongfou) at mature ripening stage (Table 1). (Dongfou) gave maximum fresh weight of 50 fruits $(183.9 \mathrm{~g})$ while minimum ( $40.9 \mathrm{~g}$ ) fresh weight of fifty fruits was obtained from $\mathrm{V}_{2}$ (Kajoli) (Table 10). On the other hand, highest dry weight was recorded from $\mathrm{V}_{5}$ (Dongfou; $19.4 \mathrm{~g}$ ) while lowest dry weight of fifty-fruits was scored from $\mathrm{V}_{2}$ (Kajoli; $10.3 \mathrm{~g}$ ) (Table 2). Fruiting character also varies on the germplasm character and environment adaptation. Fresh and dry weight of 50 fruits varied from lines to lines and results of that study supports the findings of the current experiment (Mehraj et al., 2014; Chowdhury et al., 2015). Similar result was also obtained by Ukkund et al. (2007).

\section{Fruit length and diameter}

Significant variation was recorded for fruit length among chilli germplasms. Results indicate that the longest fruit length $\left(93.7 \mathrm{~mm}\right.$ ) was recorded from $\mathrm{V}_{5}$ (Dongfou) while $\mathrm{V}_{2}$ (Kajoli) was shortest $(58.3 \mathrm{~mm})$, followed by $\left(\mathrm{V}_{1} ; 60.8 \mathrm{~mm}\right)$ (Table 1). Fruit diameter of the five chilli germplasms ranged from $9.9 \mathrm{~mm}$ to $7.8 \mathrm{~mm}$. The mature fruits of $\mathrm{V}_{5}$ (Dongfou) showed maximum fruit diameter $(9.9 \mathrm{~mm})$, which was identical with $\mathrm{V}_{1}$ (Akashi; $\left.9.7 \mathrm{~mm}\right)$ and minimum $7.8 \mathrm{~mm}$ was recorded in $\mathrm{V}_{4}$ (Bogur morich), followed by $\mathrm{V}_{2}$ (Kajoli; $7.9 \mathrm{~mm}$ ) (Table 2). Hosmani (1982) suggested that in case of chilli fruits length and diameter is having market value because normally medium to long fruit are preferred by customers. But extra-large fruit is undesirable because it is usually associated with lower productivity irregular fruit shape and poor quality by Pochard (1966). Smitha and Basavaraja (2006) observed significant differences among the chilli genotypes in respect of fruit length.

Table 2: Performance of five local landrace chilli germplasms related to growth and yield ${ }^{\mathrm{Y}}$

\begin{tabular}{lcccccccc}
\hline Germplasms $^{\mathbf{x}}$ & $\begin{array}{c}\text { Chlorophyll } \\
\text { percentage } \\
(\%) \text { at mature } \\
\text { stage }\end{array}$ & $\begin{array}{c}\text { Leaf area } \\
\left(\mathbf{c m}^{2}\right) \text { at } \\
\mathbf{8 5} \mathbf{~ D A T}\end{array}$ & $\begin{array}{c}\text { Days to flower } \\
\text { bud initiation } \\
\text { after } \\
\text { transplanting }\end{array}$ & $\begin{array}{c}\text { Number } \\
\text { of flowers } \\
\text { plant }^{-1}\end{array}$ & $\begin{array}{c}\text { Weight } \\
\text { of 50 } \\
\text { fresh } \\
\text { fruit (g) }\end{array}$ & $\begin{array}{c}\text { Weight } \\
\text { of 50 dry } \\
\text { fruit }(\mathbf{g})\end{array}$ & $\begin{array}{c}\text { Fruit } \\
\text { length } \\
(\mathbf{m m})\end{array}$ & $\begin{array}{c}\text { Fruit } \\
\text { diameter } \\
(\mathbf{m m})\end{array}$ \\
\hline $\mathrm{V}_{1}$ & $54.8 \mathrm{ab}$ & $89.6 \mathrm{~b}$ & $51.6 \mathrm{~b}$ & $64.6 \mathrm{~b}$ & $47.2 \mathrm{c}$ & $12.8 \mathrm{~b}$ & $60.8 \mathrm{~d}$ & $9.7 \mathrm{a}$ \\
$\mathrm{V}_{2}$ & $56.9 \mathrm{a}$ & $84.6 \mathrm{~b}$ & $49.2 \mathrm{~b}$ & $81.0 \mathrm{a}$ & $40.9 \mathrm{e}$ & $10.3 \mathrm{~d}$ & $58.3 \mathrm{~d}$ & $7.9 \mathrm{c}$ \\
$\mathrm{V}_{3}$ & $54.4 \mathrm{~b}$ & $62.4 \mathrm{c}$ & $46.3 \mathrm{c}$ & $62.8 \mathrm{~b}$ & $44.7 \mathrm{~d}$ & $11.7 \mathrm{c}$ & $65.9 \mathrm{c}$ & $8.8 \mathrm{~b}$ \\
$\mathrm{~V}_{4}$ & $52.5 \mathrm{~b}$ & $81.2 \mathrm{~b}$ & $39.1 \mathrm{~d}$ & $56.5 \mathrm{c}$ & $49.5 \mathrm{~b}$ & $13.6 \mathrm{~b}$ & $70.6 \mathrm{~b}$ & $7.8 \mathrm{c}$ \\
$\mathrm{V}_{5}$ & $48.9 \mathrm{c}$ & $125.8 \mathrm{a}$ & $61.1 \mathrm{a}$ & $24.6 \mathrm{~d}$ & $183.9 \mathrm{a}$ & $19.4 \mathrm{a}$ & $93.7 \mathrm{a}$ & $9.9 \mathrm{a}$ \\
$\mathrm{CV}(\%)$ & 5.3 & 11.8 & 6.7 & 7.5 & 2.1 & 2.1 & 3.3 & 0.5 \\
LSD $(0.05)$ & 2.3 & 2.3 & 2.7 & 3.6 & 3.5 & 8.1 & 5.7 & 7.3 \\
\hline
\end{tabular}

${ }^{\mathrm{x}} \mathrm{V}_{1}$, Akashi ; $\mathrm{V}_{2}$, Kajoli ; $\mathrm{V}_{3}$, Deshi kacha morich ; $\mathrm{V}_{4}$, Bogra Morich ; $\mathrm{V}_{5}$, Dongfou

$\mathbf{Y}$ Means values are statistically identical and differ significantly at $\mathrm{P}<0.05$

\section{Vitamin C content in green fruit (mg/100g)}

Significant differences were observed among the local chilli germplasms in respect of vitamin $\mathrm{C}$ content. The ascorbic acid content of the green fruits of five chilli germplasms ranged from 76.4 $\mathrm{mg} / 100 \mathrm{~g}$ fruit to $57.9 \mathrm{mg} / 100 \mathrm{~g}$ fruit. The green fruits of $\mathrm{V}_{1}$ (Akashi) contained the higher amount of ascorbic acid $\left(76.4 \mathrm{mg} / 100 \mathrm{~g}\right.$ fruit) and the lower $\left(57.9 \mathrm{mg} / 100 \mathrm{~g}\right.$ fruit) was recorded in $\mathrm{V}_{3}$ (deshi kacha morich) (Table 3). Further, significant differences showed among the germplasm with respect to both quantitative and qualitative characters Smitha and Basavaraja (2006). Similar result was reported by Ukkund et al., (2007). Apparently, genetic variation is subjected not only the morphological characters, but also qualitative characters and physiological performance including chlorphyll content and vitamin C. for this condition, chlorophyll content ranged from 60.9 to 52.8 studied among four chilli cultivars obtained by Chowdhury et al. (2015). 


\section{Vitamin $C$ content in dry fruit $(\mathbf{m g} / \mathbf{1 0 0 g})$}

Significant variations were found among the germplasms in respect of ascorbic acid content in dry fruits. Maximum amount of ascorbic acid (42.6 mg/100 g fruit) was measured in germplasm $\left(\mathrm{V}_{1}\right)$ Akashi, while minimum $(28.3 \mathrm{mg} / 100 \mathrm{~g})$ ascorbic acid was found in germplasm $\left(\mathrm{V}_{3}\right)$ Deshi kacha morich (Table 3). The stability and accumulation of Vit-C in fruits of Capsicum was affected by maturation and storage conditions besides genetic diversity (Howard et al., 2000; Jimenez et al., 2003). In chilli germplasm nutritional composition varies from germplasm to germplasm (Kaur et al., 1980).

\section{Percentage of protein in green fruit}

Protein content showed significant inequality among the germplasm variation. Protein content in fruit ranged from 4.2 to $3.0 \%$. The highest protein content $(4.2 \%)$ was recorded from $\mathrm{V}_{5}$ (Dongfou) and the lowest protein contents $(3.0 \%)$ was recorded from $\mathrm{V}_{2}$ (Kajoli) (Table 3). This might be due to the genetic variation in term of protein synthesis among the germplasms. Purseglove (1968) found that chilli fruits contain 3 percent protein. Similar result was also observed by Srivestava and Sanjeev (1994) and Leung et al. (1972).

\section{Single fruit fresh weight}

Individual fruit fresh weight was documented statistical significance among different chilli germplasms like as $\mathrm{V}_{1}$ (Akashi), $\mathrm{V}_{2}$ (Kajoli), $\mathrm{V}_{3}$ (Deshi kacha morich), $\mathrm{V}_{4}$ (Bogra morich), $\mathrm{V}_{5}$ (Dongfou). Highest individual fruit weight $\left(3.9 \mathrm{~g}\right.$ ) was obtained from $\mathrm{V}_{5}$ (Dongfou); whereas the lowest (1.4 g) from $\mathrm{V}_{2}$ (Kajoli) (Table 3). Obidiebube et al. (2012) also found variation in the fresh weight of single fruit among the cultivars of pepper.

\section{Fruits plant $\mathbf{t}^{-1}$}

Number of fruit plant ${ }^{-1}$ varied significantly for germplasm variation. The result indicates that the highest number of fruits (268.3 plant $^{-1}$ ) was obtained from the germplasm $V_{2}$ (Kajoli). Second highest (242.7) from germplasm $V_{4}$ (Deshi kacha morich) which was statistically similar with germplasm $\mathrm{V}_{1}$ (Akashi) producing (238.5) number of fruit germplasm $\mathrm{V}_{5}$ (Dongfou) attained the lowest (61.42) number of fruits plant ${ }^{-1}$ (Table 3). Obidiebube et al. (2012) found similar result i.e. significant variation from one cultivar to another in number of fruit of chilli. Sreelathakumary et al. (2004) observed higher phenotypic and genotypic co-efficient of variation for fruits plant ${ }^{-1}$.

\section{0 seeds weight}

The 1000 seed weight showed significant variation among the different germplasms viz. $\mathrm{V}_{1}$ (Akashi), $\mathrm{V}_{2}$ (Kajoli), $\mathrm{V}_{3}$ (Deshi kacha morich), $\mathrm{V}_{4}$ (Bogra morich), $\mathrm{V}_{5}$ (Dongfou). Highest 1000 seed weight (3.5 g) was found in Akashi $\left(\mathrm{V}_{1}\right)$ whereas non significant variation with $\mathrm{V}_{2}$ (kajoli).The lowest 1000 seed weight $(2.9 \mathrm{~g})$ was obtained from Bogra morich $\left(\mathrm{V}_{4}\right)$ whereas nonsignificant variation with deshi kacha morich $\left(\mathrm{V}_{3}\right)$ (Table 3). Similar result was obtained by Gogoi et al. (2002).

\section{Yield plant $^{-1}$}

Significant variations in yield plant $^{-1}$ were noticed among the germplasm. Yield of five chilli germplasms ranged from 568.6 to $171.2 \mathrm{~g}$ per plant .The higher $\left(568.6 \mathrm{gm} \mathrm{plant}^{-1}\right)$ was found in $\mathrm{V}_{1}$ (Akashi). The lower yield (171.2 $\mathrm{g}_{\text {plant }}{ }^{-1}$ ) was noted from the germplasm of $\mathrm{V}_{4}$ (Bogra morich) (Table 3). Obidiebube et al. (2012) found similar result i.e. significant variation from one cultivar to another in number of fruit of chilli. Sreelathakumary et al. (2004) observed higher phenotypic and genotypic co-efficient of variation for fruits plant ${ }^{-1}$ as well as other yield character, and Ullah et al. (2011) supported with the results on chilli yield that depend on genotypes. 


\section{Fresh fruit yield ha ${ }^{-1}$}

The fresh fruit yield $\mathrm{ha}^{-1}$ showed significant variation among the different chilli germplasms. The germplasm Akashi $\left(\mathrm{V}_{1}\right)$ gave the highest fruit yield $\left(18.1 \mathrm{t} \mathrm{ha}^{-1}\right)$. The lowest fresh fruit yield $(13.3 \mathrm{t}$ $\mathrm{ha}^{-1}$ ) was obtained from $\mathrm{V}_{4}$ (Bogra morich) (Table 3). Similar result was obtained by Purseg love (1968) and Bajaj et al. (1980).

Table 3: Performance of chilli germplasm related to chemical and yield ${ }^{\mathrm{Y}}$

\begin{tabular}{|c|c|c|c|c|c|c|c|}
\hline Germplasms ${ }^{\mathrm{X}}$ & $\begin{array}{c}\text { Vitamin } \mathrm{C} \\
\text { content in green } \\
\text { fruit }(\mathrm{mg} / 100 \mathrm{~g})\end{array}$ & $\begin{array}{c}\text { Vitamin C } \\
\text { content in dry } \\
\text { fruit }(\mathrm{mg} / 100 \mathrm{~g}) \\
\end{array}$ & $\begin{array}{c}\text { Percentage } \\
(\%) \text { of protein } \\
\text { in green fruit }\end{array}$ & $\begin{array}{l}\text { Fruits } \\
\text { plant }^{-1}\end{array}$ & $\begin{array}{l}1000 \text { seed } \\
\text { weight }(g)\end{array}$ & $\begin{array}{c}\begin{array}{c}\text { Yield } \\
\text { plant }^{-1} \\
(\mathrm{~g})\end{array} \\
\end{array}$ & $\begin{array}{c}\text { Fresh } \\
\text { fruit yield } \\
\text { (t ha-1) } \\
\end{array}$ \\
\hline $\mathrm{V}_{1}$ & $76.4 \mathrm{a}$ & $42.6 \mathrm{a}$ & $3.5 \mathrm{~b}$ & $238.5 \mathrm{~b}$ & $3.5 \mathrm{a}$ & $568.6 \mathrm{a}$ & $18.1 \mathrm{a}$ \\
\hline $\mathrm{V}_{2}$ & $61.8 \mathrm{c}$ & $34.3 \mathrm{c}$ & $3.0 \mathrm{~d}$ & $268.3 \mathrm{a}$ & $3.4 \mathrm{a}$ & $371.8 \mathrm{c}$ & $15.2 \mathrm{c}$ \\
\hline $\mathrm{V}_{3}$ & $57.9 \mathrm{~d}$ & $28.3 \mathrm{~d}$ & $3.4 \mathrm{bc}$ & $242.7 b$ & $3.1 \mathrm{~b}$ & $488.4 \mathrm{~b}$ & $16.9 \mathrm{~b}$ \\
\hline $\mathrm{V}_{4}$ & $69.4 \mathrm{~b}$ & $34.7 \mathrm{c}$ & $3.4 \mathrm{c}$ & $78.0 \mathrm{c}$ & $2.9 \mathrm{~b}$ & $171.2 \mathrm{e}$ & $13.3 \mathrm{~d}$ \\
\hline $\mathrm{V}_{5}$ & $68.5 \mathrm{~b}$ & $36.3 \mathrm{~b}$ & $4.2 \mathrm{a}$ & $61.4 \mathrm{~d}$ & $3.5 \mathrm{a}$ & $228.0 \mathrm{~d}$ & $14.5 \mathrm{c}$ \\
\hline $\mathrm{CV}(\%)$ & 1.64 & 3.96 & 4.15 & 4.2 & 6.8 & 11.9 & 6.3 \\
\hline LSD (0.05) & 0.9 & 1.15 & 0.12 & 6.1 & 0.2 & 35.8 & 0.8 \\
\hline
\end{tabular}

${ }^{\mathrm{x}} \mathrm{V}_{1}$, Akashi ; $\mathrm{V}_{2}$, Kajoli ; $\mathrm{V}_{3}$, Deshi kacha morich ; $\mathrm{V}_{4}$, Bogra Morich ; $\mathrm{V}_{5}$, Dongfou

${ }^{\mathbf{Y}}$ Mean means are statistically identical and differ significantly at $\mathrm{P}<0.05$

\section{CONCLUSION}

On the practical standpoint from the results, the germplasm 'Kajoli' gave the maximum plant height, number of branches plant ${ }^{-1}$, number of leaf plant $^{-1}$, flower plant $^{-1}$, fruit plant ${ }^{-1}$ and chlorophyll content of the leaf; however, fruit diameter and vitamin $\mathrm{C}$ content of the fruit were found in maximum from 'Akasi'. The germplasm 'Dongfou' performed better in respect fruit characters viz. weight of 50 fresh and dry fruits, single fruit fresh weight, fruit length, fruit diameter and protein content. Among different morphological, growth and yield contributing characters germplasm 'Kajoli' was performed better, whereas 'Dongfou' performed better in fruit quality. These germplasm 'Kajoli' could be suggested for further wider experiment on yield potentials and or recommend as potential yield increasing germplasm compared other low yielding chilli germplasm of this study.

Funding: This study received no specific financial support.

Competing Interests: The authors declared that they have no conflict of interests.

Contributors/Acknowledgement: Author 1 Designed the experiment, wrote the protocol and draft, while Author 3 and 4 helped to design the experiment and corrections of draft. Authors 5 and 6 were involved in laboratory and data analysis activities respectively. Author 2 supervised whole the process.

Views and opinions expressed in this study are the views and opinions of the authors, Asian Journal of Agriculture and Rural Development shall not be responsible or answerable for any loss, damage or liability etc. caused in relation to/arising out of the use of the content.

\section{References}

Akinyosoye, V. O. (1977). Senior tropical agriculture for West Africa. Macmillan Education Ltd. London. 100-101.

Bajaj, K. L., Gurdeep, K., \& Sooch B. S. (1980). Varietal variation in some important chemical constituents in chilli (Capsicum Annuum L.) fruits. J. Veg. Sci., 7, 48-54. view at Google scholar

BARI (2011). Krishe projukti hatboi (p.178). Horticulture Research Center, Bangladesh Agricultural Research Institute, Joydebpur, Gazipur. 
BBS (Bangladesh Bureau of Statistics). (2011). Year book of agricultural statistics of Bangladesh. Bangladesh Bureau of Statistics, Ministry of Planning, GOB. Dhaka, Bangladesh, 38. view at Google scholar

BBS (Bangladesh Bureau of Statistics). (2014). Report on the productivity survey on chilli crop. Bangladesh Bureau of Statistics, Ministry of Planning, GOB. Dhaka, Bangladesh, 6.

Chowdhury, B. (1976).Vegetables (4 ${ }^{\text {th }}$ edition). National Book (pp. 50-58). Trust, New Dehli, India.

Chowdhury, M. S. N., Hoque, F., Hasan, M., \& Jamal Uddin, A. F. M. (2015). Vegetative growth and yield Performance of Four Chilli (Capsicum frutescens) Cultivars. American-Eurasian J. Agric. Environ. Sci., 15(4), 514-517. view at Google scholar

Chuah, A. M., Lee, Y. C., Yamaguchi, Takamura, T. H., Yin, L. J., \& Matoba, T. (2008). Effect of cooking on the antioxidant properties of coloured peppers. Food Chemistry, 111(1), 2028. view at Google scholar / view at publisher

Edwards, C. D., \& Ludwing, L. J. (1975). The basis of expression of leaf photosynthesis activities (pp. 37-43). In Macelle, R. (Eds.). view at Google scholar / view at publisher

Erinle, I. D. (1989). Present status and prospects increases production of tomatoes and pepper in Nigeria. In: AVRDC Edu. Prac. Inter. Symp. Integrated Manad. Practices. pp. 536- 547. view at Google scholar

Gogoi, D., \& Gautam, B. P. (2002). Evaluation of chilli (Capsicum spp.) germplasm for fruit yield and component characters. J. Appl. Hort., 4(1), 41-44. view at Google scholar

Gomez, K. A., \& Gomez, A. A. (1984). Statistical procedures for agricultural research (p. 680). John Wiley and Sons. New York. view at Google scholar / view at publisher

Hosmani, M. M. (1982). Chillies - Mrs. Hosmani S. M. near Savonur Nawab's Bunglow. Dharwad.

Howard, L. R., Talcott, S. T., Brenes, C. H., \& Villalon, B. (2000). Changes in phytochemical and antioxidant activity of selected pepper cultivar as influenced by maturity. J. Agric. Food Chemi., 48, 1713-1720. view at Google scholar / view at publisher

Jimenez, A., Romojaro, F., Gomez, J. M., Llanos, M. R., \& Sevilla, F. (2003). Antioxidant systems and their relationship with the response of pepper fruits to storage at $20^{\circ} \mathrm{C} . J$. Agric. Food Chemi., 51, 6293-6299. view at Google scholar / view at publisher

Kaur, G., Bajaj, K. L., \& Jaiswal, S. P. (1980). Studies on variation in protein and mineral contents in dried red fruits of chilli varieties. Indian Food Packer, 34(1), 21-23. view at Google scholar

Leung, W. W., Brutrum, R. R., \& Chang, F. H. (1972). Food composition table for use in East Asia. Pub. Food and Agriculture Organization of the united States Food Policy and Nutrition Division, Rome, Italy. view at Google scholar

Mehraj, H., Haider, T., Chowdhury, M. S. N., Howlader, M. F., \& Jamal Uddin, A. F. M. (2014). Study on morpho-physiological and yield performance of four chilli (Capsicum spp.) Lines. J. Biosci. Agric. Res., 2(1), 01-07. view at Google scholar

Mini, S., \& Khader, K. M. A. (2004). Variability, heritability and genetic advance in wax type chilli (Capsicum annuum L.). Capsicum Eggplant Newsletter, 23, 49-52. view at Google scholar

Obidiebube, E. A., Eruotor, P. G., Akparobi, S. O., Emosaariue, S. O., Achebe, U. A., \& Kator, P. E. (2012). Response of four cultivars of pepper (Capsicum frutescens L.) to different levels of NPK fertilizer in rainforest agro ecological zone. Int. J. Agri. Sci., 2(12), 1143-1150. view at Google scholar

Plummer, D. T. (1971). An introduction to practical biochemistry. Tata McGraw Hill Pub. Conn: Ltd., Bombay, New Delhi. 229 p. view at Google scholar

Pochard, E. (1966). Experimental results of selection with peppers (Capsicum annuum). Ann. Amelior plant, 20, 233-256. view at Google scholar

Purseglove, J. W. (1968). Tropical crops. Dicotyledons 2. John Willey and sons. INC. New York pp. 523-530. view at Google scholar 
Sayed, S., \& Bagavandoss, M. (1980). Inheritance studies in chilli (Capsicum annuum L.). South Indian Hort, 28(1), p. 31. view at Google scholar

Singh, Y., Sharma, M., \& Sharma, A. (2009). Genetic variation, association of characters, and their direct and indirect contributions for improvement in chilli peppers. Intl. J. Vegetable Sci. 15, 340-368. view at Google scholar / view at publisher

Smitha, R. P., \& Basavaraja, N. (2006). Variability and correlation studies in chilli (Capsicum annuum L.). Karnataka J. Agric. Sci., 19(4), 888-891. view at Google scholar

Sreelathakumary, I., \& Rajamony, L. (2004). Variability, heritability and genetic advance in chilli (Capsicum annuum L.). J. Trop. Agric., 42(1-2), 35-37. view at Google scholar

Srivestava, R. P., \& Sanjeev, K. (1994). Fruits and vegetable preservation (principle and practices). Appendices-V. pp. 381-382. view at Google scholar

Udoh, J. D., Ndoh, A. B., Asuquo, E. P., \& Nyandoh, U. N. (2005). Crop production techniques for the tropics. Concept publications. Ltd, Lagos. 261-265. view at Google scholar

Ukkund, K. C., Madalageri, M. B., Patil, M. P., Mulage, R., \& Kotlkal, Y. K., (2007). Variability Studies in Green Chilli (Capsicum annuum L.). Karnataka J. Agric. Sci., 20(1), 102-104. view at Google scholar

Ullah, M. Z., Hasan, M. J., Saki, A. I., Rahman, A. H. M. A., \& Biswas, P. L. (2011). Association of correlation and causeeffect analysis among morphological traits in chili (Capsicum frutescens L.). Intl. J. BioRes. 10(6), 19-24. view at Google scholar

Veerapa, D. B. (1980). Studies on relative performance of different genotypes of sweet Pepper (C. annuum) M. Sc. Thesis, Univ. Agric. Sci., Dharwad. 